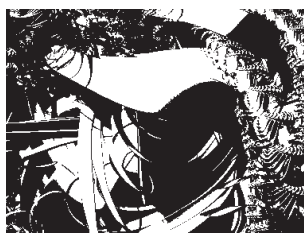

\title{
PRAVAŠKA MLADEŽ NA HRVATSKOM SVEUČILIŠTU UOČI PRVOGA SVJETSKOG RATA
}

Mislav GABELICA

Institut društvenih znanosti Ivo Pilar, Zagreb

UDK: 329(497.5)"1941":323.1

323.1(497.5)"1941"

Izvorni znanstveni rad

Primljeno: 5. 5. 2010.

Ovaj rad prikazuje pravašku ideologiju uoči Prvoga svjetskog rata na temelju analize dielovanja pravaške akademske omladine na hrvatskom Sveučilištu u tom razdoblju. Autor polazi od pretpostavke da se političke stranke u Banskoj Hrvatskoj uoči Prvoga svjetskog rata u bitnome nisu razlikovale po svojem odnosu prema državnopravnom položaju Hrvatske unutar Monarhije, nego po odnosu prema položaju Srba unutar hrvatske nacije, te od pretpostavke da je taj odnos uglavnom bio uvjetovan stajalištem prema stupanju hrvatskih zemalja u državnu zajednicu sa Srbijom. Pritom autor primjećuje tri vrste tog odnosa. Neke stranke, uglavnom jugoslavenske nacionalno-političke orijentacije, polazile su od potpune nacionalne ravnopravnosti Hrvata i Srba u Banskoj Hrvatskoj. Dio pravaša, koji je voči rata prihvatio mogućnost ostvarenja hrvatske državnosti i unutar jugoslavenskog okvira, prihvatio je i postojanje Srba unutar hrvatskoga političkog naroda. Drugi dio pravaša, koji je bezuvjetno odbacivao jugoslavenski okvir, nastavio je negirati postojanje Srba u hrvatskim zemljama, smatrajući ih skupinom nesrpskoga, vlaškog podrijetla.

Ključne riječi: pravaška ideologija, pravaška mladež, Srbi, Austro-Ugarska Monarhija, Prvi svjetski rat

$\triangle \quad$ Mislav Gabelica, Institut društvenih znanosti Ivo Pilar Marulićev trg 19/1, p. p. 277, 10001 Zagreb, Hrvatska. E-mail: Mislav.Gabelica@pilar.hr

\section{UVOD}

Uoči Prvoga svjetskog rata političke stranke u Banskoj Hrvatskoj bitno su se razlikovale po svojem nacionalnom, a ne po političkom programu. Unionistički politički program, odnosno program hrvatske autonomije unutar zemalja ugarske 
DRUŠ. ISTRAŽ. ZAGREB GOD. 20 (2011),

BR. 4 (114),

STR. 1139-1161

GABELICA, $M$. PRAVAŠKA MLADEŽ... krune, zastupalo je nekoliko političkih grupa. Sve su unionističke grupe kao svoj politički program isticale Hrvatsko-ugarsku nagodbu, kojom je zajamčeno pripajanje Dalmacije autonomnoj Banskoj Hrvatskoj. Nakon aneksije Bosne i Hercegovine, 1908. godine, povremeno su isticale i kraljevu krunidbenu prisegu, na temelju koje se moglo tražiti i pripajanje Bosne i Hercegovine Banskoj Hrvatskoj. ${ }^{1}$ Razlike su bile u nacionalnom sadržaju takva državnog okvira. U Hrvatsko-ugarskoj nagodbi državnost Banske Hrvatske istaknuta je tvrdnjom da su kraljevine Hrvatska i Slavonija politički narod. Jedna, Rauchova, grupa unionista iz ovog je izvodila zaključak da u Hrvatskoj politički narod ima isključivo hrvatsko obilježje. Ovim tumačenjem Rauchova grupa unionista postala je bliska dijelu pravaša, takozvanim frankovcima, ${ }^{2}$ iako su oni negirali zakonitost Hrvatsko-ugarske nagodbe. Druga grupa unionista, koju su činili ostaci stare Narodne stranke te Hrvatsko-srpska koalicija, stajali su na načelu hrvatsko-srpskoga narodnog jedinstva, odnosno konstitutivnosti i hrvatskoga i srpskoga naroda u Hrvatskoj (Cipek i Matković, 2006., 505-507, 630-633).

Hrvatsko-srpska koalicija, osobito njezin srpski dio, uz legalan unionistički program težila je i ostvarenju jugoslavenskoga političkog programa, odnosno stupanju "hrvatsko-srpskih" zemalja Monarhije u zajedničku državu s kraljevinom Srbijom. Premda nema pisanoga jugoslavenskog programa Koalicije, sigurno je da su njezini članovi težili stvaranju unitarne jugoslavenske države, s prevagom srpskog elementa u njoj. Na poziv velikoaustrijskoga kruga, iz hrvatskog dijela Koalicije istupio je 1908. godine dio političara, koji je odbacio politički unionizam te prihvatio politički program Stranke prava iz 1894. godine, ne odbacujući potpuno jugoslavenski nacionalno-politički program. Ta se grupa političara priključila jednoj od pravaških stranaka, Starčevićevoj stranci prava, koja je stajala na sličnim pozicijama (Gross, 1970., 26-27; Gross, 1973. 367-372; Šidak i sur., 1968., 243).

Pravaški program iz 1894. godine predviđao je ostvarenje hrvatskog ujedinjenja i pune hrvatske državnosti isključivo unutar okvira Monarhije, no nije propisivao u kakvoj bi se formi - federativnoj, trijalističkoj ili subdualističkoj - ta državnost trebala ostvariti. Izvjesno je bilo samo to da je pravašima bio neprihvatljiv uzak teritorijalni i državnopravni okvir što ga je određivala Hrvatsko-ugarska nagodba. U nacionalnom pogledu pravaši su uoči Prvoga svjetskog rata samo donekle slijedili nauk Ante Starčevića, koji je negirao povijesnu utemeljenost čitavom srpskom narodu, a slavensko podrijetlo hrvatskom narodu. Do početka 20. stoljeća svi su pravaši prihvatili tezu o slavenskom podrijetlu hrvatskoga naroda, a programskim ograničenjem hrvatskih državnopravnih zahtjeva na Bosnu i Hercegovinu prihvatili su i postojanje srpskoga naroda 
DRUŠ. ISTRAŽ. ZAGREB GOD. 20 (2011), BR. $4(114)$

STR. 1139-1161

GABELICA, $M$ : PRAVAŠKA MLADEŽ... u Srbiji. Od Starčevićeva nauka ostala je negacija srpskoga naroda u hrvatskim zemljama, kojeg su pravaši smatrali narodom nesrpskoga, dijelom vlaškoga, a dijelom slavenskoga, odnosno hrvatskoga podrijetla (Matković, 2001., 147-149).

Pravaškim raskolima iz 1908. i 1913. godine dio pravaša, okupljen u Starčevićevoj stranci prava, priklonio se jugoslavenskom nacionalno-političkom programu. U konkretnom slučaju to je značilo promjenu odnosa te grupe prema okviru Monarhije, prema srpskom pitanju u hrvatskim zemljama i prema mogućnosti stupanja u zajedničku državu sa Srbijom. Pripadnici te stranke, takozvani milinovci, beskompromisno su zahtijevali ostvarenje pune hrvatske državnosti unutar trijalistički uređene Monarhije, a u protivnom su najavljivali izlazak Hrvata iz Monarhije (Gross, 1973., 367-372). Usto, najavom priznanja posebnosti srpskoga naroda u Hrvatskoj (Gross, 1973., 404; Matković, 2001., 281) te uspostavljanjem korektnih odnosa s Hrvatsko-srpskom koalicijom, milinovci su htjeli privući hrvatske Srbe borbi za ostvarenje Velike Hrvatske, u kojoj bi bilo priznato postojanje posebnoga, srpskog, naroda i koja bi kasnije, na ravnopravnoj osnovi, stupila u zajedničku državu sa Srbijom.

Ostatak pravaša, takozvanih frankovaca, okupljenih u Starčevićevoj hrvatskoj stranci prava, odnosno Stranci prava, ostao je na čisto hrvatskim nacionalnim pozicijama, koje bi, smatrali su, u Jugoslaviji bile ugrožene prevagom srpskog elementa. Ovoj poziciji žrtvovali su programski ideal te su u pojedinim razdobljima, osim pune hrvatske državnosti u okviru Monarhije, prihvaćali i manje, odnosno postojanje autonomne, ujedinjene i nacionalno jedinstvene Hrvatske unutar državno jedinstvene Monarhije, ili isto takve Hrvatske unutar subdualistički uređenih zemalja ugarske krune, čime su se približili dijelu Rauchovih unionista, od kojih ih je u tom slučaju dijelilo samo priznanje zakonitosti Hrvatsko-ugarske nagodbe. Isprepletanja ovih ideja i programa bilo je i u omladinskim krilima hrvatskih političkih stranaka.

\section{POLITIČKO OKUPLJANJE HRVATSKE MLADEŽI}

NA POČETKU 20. STOLJEĆA

Hrvatsko akademsko podporno društvo, osnovano 1894. godine na Sveučilištu Franje Josipa I. u Zagrebu, bilo je organizacija humanitarnoga karaktera, zadužena za pomaganje siromašnim i bolesnim sveučilišnim građanima te za potporu siromašnim studentima. Po pravilima društva, njegovim članovima mogli su biti studenti hrvatske i svake druge slavenske narodnosti, koja na hrvatskom Sveučilištu nije imala vlastita potpornog društva (Pavelić, 1968., 351). Budući da su srpski studenti od 1894. godine imali vlastito, Srpsko akademsko pod- 
DRUŠ. ISTRAŽ. ZAGREB GOD. 20 (2011)

BR. 4 (114),

STR. 1139-1161

GABELICA, $M$. PRAVAŠKA MLADEŽ... porno društvo, 3 izbori za Hrvatsko akademsko podporno društvo bili su pokazatelj odnosa političkih snaga isključivo među studentima koji su se osjećali Hrvatima. Od 1894. do 1901. godine među Hrvatima na Zagrebačkom sveučilištu dominirala je pravaška mladež, okupljena u "Starčevićevoj akademskoj mladosti", koja je za to vrijeme birala i upravu Hrvatskog akademskog podpornog društva (Artuković, 1991., 70).

Pod utjecajem jugoslavenske ideologije Nezavisne narodne stranke i češke nacionalne ideologije, koja je isticala potrebu sveslavenske solidarnosti radi obrane od navodnoga njemačkog prodora na istok, na hrvatskom se Sveučilištu 1897. godine pojavila Napredna omladina, koja je 1901. godine osvojila većinu u izborima za Hrvatsko akademsko podporno društvo. Težeći stvaranju jugoslavenske federacije kao bedema protiv navodno nadirućega germanstva, naprednjaci su odbacili hrvatsku državnopravnu politiku kao zastarjelu te su prihvatili postojanje srpskoga naroda u hrvatskim pokrajinama i njegovu nacionalnu ravnopravnost s hrvatskim narodom. Do 1904. godine Napredna omladina djelovala je samostalno, simpatizirajući s domovinaško-obzoraškim dijelom opozicije, a osnutkom Napredne stranke iste godine postala je njezinom omladinskom organizacijom, od koje se nije odvajala do 1910. godine. Napredna je stranka potkraj 1905. godine, zajedno s domovinaško-obzoraškom Hrvatskom strankom prava te srpskim strankama u Banskoj Hrvatskoj, postala dijelom Hrvatsko-srpske koalicije, ustrojene na načelu hrvatsko-srpskoga narodnog jedinstva, odnosno nacionalne ravnopravnosti hrvatskoga i srpskoga naroda u hrvatskim zemljama. Unutar Hrvatsko-srpske koalicije hrvatska Napredna omladina surađivala je s omladinom Srpske samostalne stranke (Gross, 1968.-69., 77-79; Artuković, 1991., 68-72; Peršić, 2002., 147-152).

U prvom desetljeću 20. stoljeća među studentima na hrvatskom Sveučilištu dominirala je Napredna omladina, koja je $\mathrm{u}$ to vrijeme birala i upravu Hrvatskog akademskog podpornog društva. Zbog toga je pravaška mladež, 1906. godine, pokrenula inicijativu za osnivanje konkurentskoga humanitarnog društva, Starčevićanskoga akademskog podpornog društva, čiji bi članovi mogli biti samo studenti pravaši. Hrvatska vlada je, na sugestiju akademskoga senata hrvatskoga Sveučilišta, odbila potvrditi pravila toga društva, uz obrazloženje da ono nedopušteno stoji na ekskluzivno stranačkim pozicijama. Ipak, akademski je senat u sugestiji vladi smatrao i da bi u Hrvatskom akademskom podpornom društvu morali doći do izražaja i interesi snažne manjine, odnosno da bi i studenti pravaši morali biti zastupani u njegovoj upravi. ${ }^{4} \mathrm{U}$ sljedećem razdoblju, do 1911. godine, između pravaških i naprednjačkih studenata sklapani su predizborni kompromisi, po kojima su naprednjacima prepuštani položaji predsjednika i bla- 
DRUŠ. ISTRAŽ. ZAGREB GOD. 20 (2011), BR. 4 (114)

STR. 1139-1161

GABELICA, M.: PRAVAŠKA MLADEŽ... gajnika Hrvatskoga akademskog podpornog društva, a ostali položaji bili su ravnomjerno podijeljeni između pravaša i naprednjaka. ${ }^{5}$

Potkraj 1906. godine svećenici Ivan Butković i Fran Binički na Zagrebačkom su sveučilištu osnovali Hrvatsko katoličko akademsko društvo Domagoj, studentsku organizaciju Hrvatskoga katoličkog pokreta, nastalog radi afirmacije kršćanskih načela u hrvatskom javnom životu. Akademsko društvo Domagoj bilo je dio razgranate mreže hrvatskih katoličkih đačkih organizacija, koje su se 1910. godine okupile pod krovnom organizacijom, Hrvatskim katoličkim đačkim savezom (Matijević, 1998., 26-29). Studenti okupljeni oko Domagoja nisu stajali isključivo na pravaškim nacionalno-političkim pozicijama, smatrajući prvotnim ciljem rekristijanizaciju hrvatskoga društva, a ne njegovo nacionalno oslobođenje.

U predaneksijskom razdoblju Starčevićeva hrvatska stranka prava počela je sustavno organizirati hrvatsku đačku omladinu na pravaškim načelima, pa je 1907. godine stvorena krovna organizacija, Starčevićanska mladost, koja je obuhvaćala studente i učenike viših razreda srednjih škola koji su prihvaćali pravaška načela, odnosno Starčevićansku akademsku mladost i lokalne srednjoškolske starčevićanske organizacije. Na čelu ove krovne organizacije bio je upravni odbor Starčevićanske akademske mladosti, čiji su predsjednik i tajnik bili članovi Izvršnog odbora Starčevićeve hrvatske stranke prava. 6 Sljedeće, 1908., godine osnovan je središnji Savez organizacija starčevićanske srednjoškolske mladosti, na čelu sa Središnjim odborom Saveza i njegovim predsjednikom. Istodobno su osnovani pododbori toga Saveza za Bansku Hrvatsku, Dalmaciju te Bosnu i Hercegovinu, koji su bili posredujući organi između središnjeg odbora Saveza i lokalnih srednjoškolskih organizacija u pojedinoj pokrajini. Savez organizacija srednjoškolske starčevićanske mladosti i Starčevićanska akademska mladost bili su okupljeni u krovnoj organizaciji, Starčevićanskoj mladosti, te su zajedno izdavali glasilo starčevićanskoga đaštva, Mladu Hrvatsku. ${ }^{7}$ Osnutkom lista Mlada Hrvatska, 1908. godine, pravaški omladinski pokret nastavio se razvijati pod mladohrvatskim imenom.

Fuzijom Napredne stranke s konzervativnom Hrvatskom strankom prava, 1910. godine, dio Napredne omladine odvojio se od novoustrojene Hrvatske samostalne stranke te se počeo samostalno organizirati na programu jugoslavenskoga nacionalizma. Načelo hrvatsko-srpskoga narodnog jedinstva, dotad tumačeno kao izraz nacionalne ravnopravnosti hrvatskoga i srpskoga naroda u hrvatskim zemljama, u interpretaciji hrvatsko-srpske nacionalističke omladine počelo se tumačiti kao stvarno postojanje jedinstvenoga hrvatsko-srpskog naroda, koji će u jednonacionalnoj jugoslavenskoj državi steći i subjek- 
DRUŠ. ISTRAŽ. ZAGREB GOD. 20 (2011) BR. 4 (114),

STR. 1139-1161

GABELICA, $M$. PRAVAŠKA MLADEŽ... tivni osjećaj narodnoga jedinstva (Artuković, 1991., 68-74; Horvat, 2006., 92-324; Gross, 1973., 387-393). Drugi dio Napredne omladine ostao je vezan uz Hrvatsku samostalnu stranku, odnosno uz Hrvatsko-srpsku koaliciju. U isto vrijeme srpska je omladina ostala nepodijeljena i čvrsto vezana uz Srpsku samostalnu stranku (Gross, 1968.-69., 104-110).

Sljedeće, 1911., godine hrvatski naprednjaci izgubili su većinu na Zagrebačkom sveučilištu te su do 1913. godine potpuno nestali s hrvatskoga Sveučilišta, prepuštajući mjesto nacionalističkoj omladini, organiziranoj u akademskom klubu Svačić. Unutar nacionalističke omladine na hrvatskom Sveučilištu djelovali su i srpski studenti. ${ }^{8}$ Pritom srpski studenti nisu raspustili svoje posebne studentske institucije, srpski literarni klub Njegoš, te Srpsko akademsko podporno društvo. ${ }^{9}$ Premda formalno nezavisna, nacionalistička omladina je u predizbornoj kampanji za Hrvatski sabor, 1913. godine, agitirala za Koaliciju, dijelila joj letke, lijepila plakate te je organizirano sudjelovala na njezinim predizbornim skupovima. ${ }^{10} \mathrm{U}$ idućem je razdoblju nacionalistička omladina na hrvatskom Sveučilištu sve svoje službene izjave objavljivala u tisku Hrvatsko-srpske koalicije.

Mladohrvatski se pokret $\mathrm{u}$ prve dvije godine postojanja bavio prije svega organiziranjem srednjoškolske mladeži na pravaškim načelima, pod vodstvom Starčevićeve hrvatske stranke prava. Nezadovoljni fuzijom svoje matične stranke, Starčevićeve hrvatske stranke prava, s kršćansko-socijalnom, pravaškom grupom okupljenom oko lista Hrvatstvo, mladohrvatski pokret se na prvom mladohrvatskom zboru, održanom 1910. godine u Zagrebu, službeno odvojio od fuzionirane Stranke prava i proglasio se samostalnom političkom grupom. Na istom je zboru osnovana krovna organizacija frankovske omladine, Savez mladohrvatskih organizacija, u koju su se uključile frankovske đačke organizacije iz čitave Austro-Ugarske Monarhije. ${ }^{11}$ Iste je godine na hrvatskom Sveučilištu osnovan Hrvatski akademski klub Kumičić, koji je, po riječima nekih svojih pripadnika, bio "reprezentativni mladohrvatski klub u Savezu mladohrvatskih organizacija".12

Nova je Stranka prava, fuzionirana s hrvatskim kršćanskim socijalima, pravašima, pozvala Hrvatski katolički đački savez da im se pridruži, što je ta đačka organizacija, koja nije stajala na isključivo pravaškim pozicijama i koja je rekristijanizaciju hrvatskoga društva smatrala svojim primarnim ciljem, odbila. ${ }^{13}$ Unatoč nepristajanju Hrvatskoga katoličkog đaštva uz pravaški program, Stranka prava podržavala je rad Hrvatskoga akademskog društva Domagoj, a zapostavljala djelatnost liberalne pravaške, mladohrvatske omladine (Kršnjavi, 1986., 647). Bez čvrstoga političkog vodstva mladohrvatski je pokret počeo idejno lutati i granati se u nekoliko smjerova. 
DRUŠ. ISTRAŽ. ZAGREB GOD. 20 (2011), BR. 4 (114)

STR. 1139-1161

GABELICA, M.: PRAVAŠKA MLADEŽ..
Tokom 1911. godine veći dio pravaške omladine, okupljen oko lista Mlada Hrvatska, s ideolozima Josipom Matasovićem i Milom Budakom, nastavio je djelovati s frankovskih, velikohrvatskih nacionalnih pozicija (Gross, 1968.-69., 97-100, 102). Drugi dio, pod duhovnim vodstvom Antuna Gustava Matoša, kombinirajući političko hrvatstvo i kulturno jugoslavenstvo, uz simpatiziranje Napredne omladine, bio je bliži milinovačkoj Starčevićevoj stranci prava. Ovaj se dio kratkotrajno okupljao oko lista Stekliš. ${ }^{14}$ Od te su se grupe, potkraj 1911. godine, odvojili Tin Ujević i Krešimir Kovačić, koji su prihvatili ideju hrvatsko-srpskoga nacionalnog jedinstva i identificirali se s jugoslavenskom nacionalističkom omladinom (Gross, 1968.-69., 102-103, 121-124, 127-129). Jedinstvo mladohrvatske omladine ostalo je sačuvano u zajedničkoj instituciji koja je okupljala sve mladohrvatske organizacije, Savezu mladohrvatskih organizacija.

Potkraj 1911. godine mladohrvatska je omladina pozdravila stvaranje svepravaške organizacije. ${ }^{15}$ Iste godine mladohrvatska je omladina stekla većinu na Zagrebačkom sveučilištu te je na izborima za upravni odbor Hrvatskog akademskog podpornog društva, održanima u studenom 1911. godine, pobijedila Naprednu omladinu. U prvom izbornom krugu domagojci nisu podržali pravašku listu, nego su izašli s vlastitom listom, kojom su pravašima oduzeli glasove potrebne za potpunu pobjedu. Na užim izborima pravaška je lista odnijela pobjedu. Tom je prilikom za pravaše glasovao i dio domagojaca, no njihovi glasovi nisu bili presudni za pravašku pobjedu. Nakon izbora u Mladoj Hrvatskoj objavljen je uvodni članak, u kojem su domagojci opisani u najcrnjem svjetlu, a naprednjaci proglašeni mogućim saveznicima protiv "abnormalnog vjerskog fanatizma" domagojaca. ${ }^{16}$

Tijekom izleta hrvatskih studenata u Srbiju, u travnju 1912. godine, predsjednik Hrvatskog akademskog podpornog društva, pravaš Janko Baričević, službeno je, uime hrvatskih studenata, istupio s jugoslavenskih pozicija. Među pravaškim studentima nije bilo ideološke homogenosti, pa je Baričević zbog svojega istupa doživio kritiku svojega studentskog kluba, zbog čega je ponudio ostavku na položaj predsjednika Hrvatskog akademskog podpornog društva, no uprava Hrvatskog akademskog podpornog društva, u kojoj su pravaši imali većinu, ostavku nije prihvatila (Gross, 1968.-69., 119-120). Tokom 1913. godine srpske pobjede $\mathrm{u}$ balkanskim ratovima uzrokovale su daljnje osipanje mladohrvatske omladine i daljnje uvlačenje jugoslavenstva u mladohrvatske organizacije. $U$ tomu su prednjačile dalmatinske mladohrvatske organizacije, dok su bosanskohercegovačke većinom ostajale na čisto hrvatskim pozicijama. ${ }^{17}$ 
DRUŠ. ISTRAŽ. ZAGREB GOD. 20 (2011) BR. 4 (114),

STR. 1139-1161

GABELICA, $M$. PRAVAŠKA MLADEŽ...
Te je godine predsjednik mladohrvatskoga saveza bio student na Bečkom sveučilištu, Ivan Žilić, a predsjednik akademskoga kluba Kumičić i urednik Mlade Hrvatske bio je student prava na hrvatskom Sveučilištu, Ljubomir Maštrović. ${ }^{18}$ Nakon pravaškoga raskola, u svibnju 1913. godine, na hrvatskom je Sveučilištu u organizaciji frankovačkoga krila Stranke prava sazvana mladohrvatska skupština, koja je trebala odlučiti kakvo će stajalište zauzeti studenti pravaši prema najnovijem sporu unutar Stranke prava. Na skupštini je stvoren zaključak da mladohrvati ne odobravaju raskol te da se ne pridružuju ni jednoj pravaškoj grupi, nego da odobravaju i podupiru svaki domoljubni čin i jedne i druge pravaške grupe. ${ }^{19}$ Neutralnom izjavom privremeno je spriječen konačan raskol u mladohrvatskoj organizaciji.

\section{ODNOS SNAGA NA HRVATSKOM SVEUČILIŠTU UOČI PRVOGA SVJETSKOG RATA}

Potkraj 1913. godine pripremali su se redoviti izbori za upravu Hrvatskog akademskog podpornog društva. U listopadu te godine novoformirana jugoslavenska nacionalistička omladina na hrvatskom je Sveučilištu pokušala, upisom srpskih studenata u Hrvatsko akademsko podporno društvo, osigurati većinu na izborima. Srpski studenti na hrvatskom Sveučilištu birali su upravu vlastitoga, Srpskoga akademskog podpornog društva, a od školske godine 1912./1913., na temelju tzv. proporcionalnog izbornog sistema, dobili su pravo delegirati predstavnika i u Hrvatsko akademsko podporno društvo. Formiranjem jugoslavenske nacionalističke omladine na hrvatskom Sveučilištu, srpski su studenti zadržali posebne srpske institucije, ali su istodobno, kao dio jugoslavenske nacionalističke omladine, tražili ravnopravno sudjelovanje na izborima za hrvatske sveučilišne institucije. Prilikom upisivanja u Hrvatsko akademsko podporno društvo, srpski sveučilištarci su se, iz taktičkih razloga, izjasnili kao Hrvati, kako bi zadovoljili uvjete upisa u Hrvatsko akademsko podporno društvo i pridonijeli pobjedi jugoslavenskih nacionalista. Hrvatski studenti, pravaši i domagojci, uvidom u upisne formulare, gdje su se srpski studenti mahom izjasnili kao Srbi, dokazali su pokušaj prijevare te su ih isključili iz Hrvatskog akademskog podpornog društva. ${ }^{20}$ Nakon toga u Hrvatskom akademskom podpornom društvu ostao je samo jedan pravoslavac, senjski frankovac Vladimir Ćopić.

Isključenjem Srba iz Hrvatskog akademskog podpornog društva jugoslavenska je nacionalistička omladina bojkotirala studentske izbore, ističući da ne priznaje Hrvatsko akademsko podporno društvo kao svojega predstavnika na hrvatskom Sveučilištu. Tokom ovih događanja sklopljen je savez pravaške akademske omladine $\mathrm{s}$ domagojcima. ${ }^{21}$ Unatoč to- 
DRUŠ. ISTRAŽ. ZAGREB GOD. 20 (2011), BR. 4 (114)

STR. 1139-1161

GABELICA, $M$ : PRAVAŠKA MLADEŽ... mu, na glavnoj skupštini akademskoga kluba Kumičić, održanoj 8. studenog 1913. godine, ponovo izabrani predsjednik kluba za školsku godinu 1913./1914., Ljubomir Maštrović, kao glavne protivnike mladohrvatskoga pokreta istaknuo je nacionalističku omladinu i klerikalizam.22

Sredinom studenoga 1913. godine dio studenata iz akademskoga kluba Kumičić, navodno uime cjelokupne pravaške omladine, javno je podržao Starčevićevu stranku prava kao pravu Stranku prava. ${ }^{23} \mathrm{Na}$ to je veći dio akademskoga kluba Kumičić, također uime cjelokupne pravaške akademske omladine, demantirao studentsku podršku politici Mile Starčevića. ${ }^{24}$ Unatoč nesuglasicama, pravaška je mladež potkraj studenog 1913. godine zajednički istupila na studentskim izborima, na kojima je odnijela pobjedu. Za predsjednika Hrvatskog akademskog podpornog društva, glasovima pravaša i domagojaca, izabran je musliman, frankovac Salih Baljić,25 predsjednik novoutemeljenoga Kluba Hrvata muslimana akademičara iz Herceg-Bosne (Hasanbegović, 2007., 45). Glasilo hrvatskoga dijela Hrvatsko-srpske koalicije zabilježilo je da je po želji frankovaca predsjednikom Hrvatskog akademskog podpornog društva postao Turčin. ${ }^{26}$ Potpredsjednik podpornoga društva postao je pravaš Makso Milošević, a blagajnik pravaš Ante Nikšić. ${ }^{27}$ Dok su pravaši slavili pobjedu, nacionalistička omladina je organizirala demonstracije, na kojima su se pjevale srpska i crnogorska himna. Tijekom demonstracija na Strossmayerovo poprsje, u sveučilišnoj auli, položen je vijenac sa srpskom, hrvatskom i slovenskom trobojnicom. ${ }^{28}$

Nakon završenih izbora na hrvatskom Sveučilištu, u glasilu Starčevićeve stranke prava, javio se student Ilija Despot, član pravaške akademske omladine, koji je naveo da u pravaškoj pobjedi na Sveučilištu nije pobijedio frankovski, "čisti kurs", koji je predstavljao radikalno protivljenje srpskoj nacionalnoj ideji u hrvatskim zemljama i bezuvjetnu lojalnost Monarhiji, nego da dio pravaške omladine više simpatizira jugoslavensku nacionalističku omladinu. U tom je članku Despot istaknuo da su on i njegovi "istomisleći drugovi" u borbi protiv frankovaca spremni surađivati i sa srpskom omladinom, ako ona i "njihovi stariji" budu "stajali na stanovištu recipročna bratskog djelovanja", 29 odnosno ako pristanu biti priznata manjina unutar hrvatskih institucija.

Ovaj je dio pravaške omladine 30. studenog 1913. godine uime cjelokupne pravaške omladine osudio politiku Stranke prava, bezuvjetnu dinastičnost $i$ tumačenje da se pravaški program može ostvariti u dualizmu te je objavio priključenje Vrhovnoj upravi stranke prava za sve hrvatske zemlje, odnosno Starčevićevoj stranci prava. ${ }^{30}$ Potom se ta grupa pravaške mladeži odvojila od akademskoga kluba Kumičić i osnovala vlastiti klub, Kvaternik, na čelu s Antom Nikšićem. Potpred- 
DRUŠ. ISTRAŽ. ZAGREB GOD. 20 (2011) BR. 4 (114),

STR. 1139-1161

GABELICA, $M$. PRAVAŠKA MLADEŽ... sjednik toga kluba postao je Miroslav Bošnjak, a blagajnik Franjo Vukelić. ${ }^{1}$ U veljači 1914. godine akademski klub Kvaternik počeo je izdavati list Pravaš, pod uredništvom Blaža Jurišića. ${ }^{32}$ Veći dio pravaške sveučilišne omladine, u izjavi akademskoga kluba Kumičić, osudio je postupak "nekolicine akademičara, tzv. milinovaca", kojem je, po njihovu sudu, bila svrha posvaditi pravaše uoči saborskih izbora. Tom je prilikom pravaška omladina iz Kumičića osudila i Starčevićevu stranku prava zbog navodnoga podupiranja Koalicije te je odobrila dosadašnji rad Stranke prava i pisanje njezina glasila, Hrvatske. ${ }^{33}$ Time je pravaška omladina, okupljena u akademskom klubu Kumičić, službeno priznala frankovačku struju kao pravu Stranku prava. Uz Ljubomira Maštrovića i Saliha Baljića, frankovce su između ostalih podržali i Vladimir Ćopić, Osmanbeg Kulenović, Mile Budak, Ante Pavelić te predsjednik kluba hrvatskih akademičara iz Herceg-Bosne Tvrdko, Đuro Krešić. ${ }^{34}$

Potaknuti izjavom podrške Stranci prava, iz akademskoga kluba Kumičić istupila su još dvanaestorica njegovih članova, na čelu s Maksom Miloševićem i Mićom Anićem, koji su 14. prosinca 1913. godine u Obzoru izjavili da su pravaški studenti, i podržavajući Stranku prava, porekli sva bitna obilježja mladohrvatskoga pokreta. ${ }^{35}$ Odgovorio im je predsjednik mladohrvatskoga Saveza, Ivan Žilić, koji je izjavio da je Mlada Hrvatska oduvijek ispovijedala oštru i nepomirljivu borbu protiv Koalicije te osuđivala njihove doušnike u pravaškim redovima. Pišući o Stranci prava, Žilić je rekao da je mladohrvatski pokret uvijek, pa i u razdoblju emancipacije, smatrao ispravnom samo politiku Stranke prava, iako se od Frankove smrti nije slagao s njezinim unutrašnjim uređenjem. Pišući o daljnjoj sudbini mladohrvatskoga pokreta, Žilić je izjavio da mladohrvatski pokret, iako zasad neovisan, traži sporazum sa Strankom prava. ${ }^{36}$

Potkraj prosinca 1913. godine Predsjedništvo mladohrvatskoga Saveza sazvalo je mladohrvatsku konferenciju, na koju je pozvalo sve organizacije upisane $u$ mladohrvatski Savez. Na konferenciju se većina pozvanih organizacija nije pojavila. ${ }^{37}$ Odazvalo se nekoliko mladohrvatskih organizacija iz Bosne i Hercegovine, gdje je 27. prosinca 1913. godine osnovan i pododbor Saveza mladohrvatskih organizacija, koji je podržavao frankovsko vodstvo Saveza. ${ }^{38}$ Namjera organizatora mladohrvatske konferencije bila je uključiti mladohrvatske organizacije $\mathrm{u}$ krilo frankovske Stranke prava. Predsjednik akademskoga kluba Kumičić, Ljubomir Maštrović, u govoru je upozorio na pogrešku pri emancipiranju mladohrvatskoga pokreta od Stranke prava, zbog čega se, po njegovim riječima, u izvorno frankovski mladohrvatski pokret uvuklo mnogo onih koji ovamo, po svojem ideološkom profilu, nisu pripadali. Maštrović je dokazivao organsku povezanost mladohrvatsko- 
DRUŠ. ISTRAŽ. ZAGREB GOD. 20 (2011), BR. 4 (114)

STR. 1139-1161

GABELICA, $M$ : PRAVAŠKA MLADEŽ... ga pokreta sa Strankom prava, održanu i za vrijeme emancipiranosti mladohrvatskoga pokreta, te pozvao na ponovno uključenje mladohrvatskih organizacija u Stranku prava. ${ }^{39}$

Na početku siječnja 1914. godine Upravni odbor Saveza mladohrvatskih organizacija sve je poslove Saveza prenio na upravni odbor Kumičića. Time je vodstvo akademskoga kluba Kumičić postalo i vodstvo Saveza mladohrvatskih organizacija. Akademski klub Kumičić postao je ovlašten izdavati list Mlada Hrvatska, za čiji je sadržaj i program odgovarao mladohrvatskim organizacijama upisanima u mladohrvatski Savez. ${ }^{40}$ Na Izvanrednoj skupštini akademskoga kluba Kumičić, održanoj 31. siječnja 1914. godine, klub je stupio u usku vezu sa Strankom prava, napustio neovisnost u političkim pitanjima, a zadržao neovisnost u kulturnim pitanjima, ostavši na liberalnim, odnosno antiklerikalnim, pozicijama. ${ }^{41} \mathrm{Na}$ početku ožujka izabran je nov upravni odbor Kumičića. Predsjednikom je ostao Ljubomir Maštrović, za potpredsjednika je izabran Viktor Magerl, a za tajnika Ivan Smilaj. ${ }^{42}$

Dvanaestorica disidenata iz Kumičića osnovali su na Sveučilištu poseban klub, Mladu Hrvatsku, na čelu kojeg se našao Makso Milošević. U veljači 1914. godine akademski klub Mlada Hrvatska poslao je okružnicu svim mladohrvatskim organizacijama, u kojoj ih je pozvao da pismeno izraze nepovjerenje predsjedništvu mladohrvatskoga Saveza, koje je bez dozvole mladohrvatskih organizacija predalo ovlasti Saveza i izdavanje lista Mlada Hrvatska akademskom klubu Kumičić. U okružnici je istaknuto da mladohrvatski pokret, od svojega nastanka, nikad nije bio pomladak ni jedne stranke, nego skupina s vlastitim političkim pretenzijama. Zbog toga je kritizirano strančarenje skupine okupljene u Kumičiću i one okupljene u Kvaterniku te je pozvano članstvo mladohrvatskih organizacija da otkaže pretplatu na listove Mlada Hrvatska i Pravaš. U okružnici je jače kritiziran oportunizam "frankofurtimaških" studenata okupljenih u klubu Kumičić nego koketiranje s jugoslavenstvom studenata okupljenih u klubu Kvaternik. ${ }^{43}$ U budućem djelovanju studenti okupljeni u klubu Mlada Hrvatska usko su surađivali sa studentima iz kluba Kvaternik. U jednom članku, objavljenom u veljači 1914. godine u listu frankovske omladine, Mladoj Hrvatskoj, navedeno je da studenti okupljeni u klubu Mlada Hrvatska navodno žele modificirati pravaško stanovište prema srpskom pitanju, uzevši u tomu Supila za učitelja. ${ }^{44}$

\section{IDEOLOŠKE RAZLIKE PRAVAŠKE MLADEŽI}

U programskom uvodniku prvoga broja sedmoga godišta Mlade Hrvatske aktualni predsjednik mladohrvatskoga saveza, Ivan Žilić, kritizirao je dogmatsku pravašku politiku, koja je pukim pozivanjem na hrvatsko pravo i negiranjem zakonitosti Nagodbe omogućila jačanje mađarskoga i slabljenje hrvat- 
DRUŠ. ISTRAŽ. ZAGREB GOD. 20 (2011) BR. 4 (114),

STR. 1139-1161

GABELICA, $M$. PRAVAŠKA MLADEŽ... skoga utjecaja u Monarhiji, što je koristilo srpstvu da se uvuče u hrvatski javni život. Žilić je zamjerao jednoj struji pravaša, milinovcima, da zbog pasivne politike, odnosno nepriznavanja zakonitosti Nagodbe, prepuštaju uzde javnoga života Koaliciji, koja Hrvate vodi pod srpsku dominaciju. Pisao je da pravaši mogu birati između potpune negacije Nagodbe, "pa ne će ići ni u Peštu ni u Beč, ni priznavat bana ni zemaljskog sabora ni činovnike, jer sve to u nagodbi stoji", ili će prihvatiti Nagodbu, a njezine loše dijelove pokušati izbrisati, a dobre zadržati. U kontekstu ove dileme Žilić se opredijelio: "Iz idiličnih se zakutaka mora pravaštvo jednom maknuti, jer više nije vrijeme da se dičimo svojom karakternošću, načelnošću i moralom, kad mi znamo, da sve te kreposti zajedno ne znače ništa za Hrvatsku."45 Uz idealizam Ante Starčevića, u Mladoj Hrvatskoj se njegovao i kult realne politike Josipa Franka.

U programskom uvodniku prvoga broja lista Pravaš milinovačka studentska mladež najavila je približavanje odlučnoga časa koji će Hrvatima donijeti ili slobodu ili konačnu propast. Izjavili su lojalnost Starčevićevoj Stranci prava te utemeljenost u idejama i žrtvi Ante Starčevića te Eugena Kvaternika i Vjekoslava Bacha, pravaša poginulih u ustanku kojem je bio cilj stvoriti hrvatsku državu izvan okvira Monarhije. ${ }^{46}$ U članku "Put pravaški prema nacijonalističkome", objavljenom u lipnju 1914. godine, Blaž Jurišić je istaknuo da je pravaški ideal sloboda i ujedinjenje hrvatskoga naroda, kojem nije dao nacionalni nego teritorijalni karakter naroda koji nastanjuje hrvatski državni teritorij: "Jasno je da se u taj politički hrvatski narod ubrajaju i Srbi i Slovenci u našim državnim granicama." Jurišić je zauzvrat od hrvatskih Srba tražio da kao hrvatski državljani skupa s Hrvatima rade o procvatu i slobodi hrvatske države, unutar trijalistički uređene Monarhije. Osim što bi hrvatski Srbi trebali podržati ujedinjenje hrvatskih pokrajina i stvaranje Velike Hrvatske u trijalistički uređenoj Monarhiji, Jurišić je smatrao i da bi se Srbija trebala odreći velikosrpske politike te da bi na svojem području trebala promicati ideju o stvaranju jugoslavenske države ravnopravnih naroda - hrvatskoga i srpskoga. Nakon stvaranja Velike Hrvatske i odricanja Srbije od velikosrpskoga programa, zaključio je Jurišić, u Hrvatskoj bi se povela rasprava o državnoj zajednici s ostalim južnim Slavenima. ${ }^{47}$ Birajući između idealizma i realne taktike u politici, milinovačka studentska mladež opredijelila se za idealizam, kritizirajući frankovce, koji su davali prednost realizmu Josipa Franka pred idealizmom Ante Starčevića. ${ }^{48}$

U idućem razdoblju pravaški studentski klubovi rijetko su surađivali, a na studentskim istupima milinovačka je mladež češće surađivala s nacionalističkom omladinom. Milinovačka je omladina suradnju s nacionalističkom omladinom pravdala pokušajem preodgoja nacionalističke omladine $u$ 
DRUŠ. ISTRAŽ. ZAGREB GOD. 20 (2011), BR. 4 (114)

STR. 1139-1161

GABELICA, M.: PRAVAŠKA MLADEŽ... hrvatskom duhu i pokušajem njezina odvajanja od Hrvatsko-srpske koalicije. ${ }^{9}$ Na početku prosinca 1913. godine akademski je klub Kvaternik zbog službenoga poziva banu Skerleczu na studentsku zabavu, što ga je uputio predsjednik Hrvatskoga akademskog podpornog društva, Salih Baljić, organizirao proturežimske demonstracije, kojima se pridružila nacionalistička omladina. Demonstranti su zviždanjem i vikanjem prosvjedovali i ispod stana čelnika Stranke prava, Aleksandra Horvata, optužujući frankovce kao sluge režima. ${ }^{50} \mathrm{Mjesec} \mathrm{da-}$ na kasnije, prilikom službenoga posjeta ugarskoga ministra predsjednika Zagrebu, frankovačka studentska mladež organizirala je protumađarske demonstracije, u kojima su socijalisti, milinovačka mladež ${ }^{51}$ i nacionalistička omladina ${ }^{52}$ odbili sudjelovati.

Potkraj ožujka 1914. godine sva je studentska omladina hrvatskoga Sveučilišta nastupila na prosvjednoj skupštini organiziranoj u povodu Zakona o izvlastbi hrvatske morske obale, donesenog istoga mjeseca u Ugarsko-hrvatskom saboru, gdje su ga podržali i hrvatski delegati iz redova Koalicije. Na skupštini je nacionalistička omladina nastupila s protufrankovačkom retorikom, nastojeći skrenuti pažnju s Hrvatsko-srpske koalicije i njezine podrške "izvlastbenom zakonu". Student Švrljuga je uime nacionalističke omladine napao frankovce da su prilikom veleizdajničke parnice stajali uz vlastodršce, a sada da su najradikalnija opozicija, koja će u odlučnom času opet stati u protunarodne redove. Švrljuga je zaključio da su frankovci krivi što se Koalicija ne drži energičnije i u okolnostima "izvlastbe" hrvatske obale.

Ovaj je Švrljugin govor na prosvjednoj skupštini izazvao sukob između frankovačke i nacionalističke omladine. Nakon smirivanja nereda predložene su dvije rezolucije: jedna organizacijskog odbora, u kojem je važnu ulogu imala frankovačka mladež, a druga nacionalističke omladine. Tom je prilikom pravaška omladina, okupljena u studentskim klubovima Kvaternik i Mlada Hrvatska, odbacila prijedlog rezolucije organizacijskog odbora, a prihvatila prijedlog nacionalističke omladine, koji je osim osude "izvlastbenog zakona" i držanja Koalicije u tim okolnostima, sadržavao i prosvjed protiv mogućnosti da se "protuizvlastbena akcija" akademske omladine dovede $u$ vezu s akcijom "raznih proračunanih i špekulantskih elemenata, kojima ni u ovom slučaju nije stalo do opće narodnih, nego do prljavih ličnih i klikarskih interesa."53 Ovaj se dio odnosio na Stranku prava.

Najradikalniji primjer okretanja pravaških studenata iz akademskih klubova Kvaternik i Mlada Hrvatska prema suradnji s nacionalističkom omladinom dogodio se potkraj travnja 1914. godine, prilikom obilježavanja dana pogibije Zrinskog i Frankopana. Kult Zrinskog i Frankopana stvorila je Stranka pra- 
DRUŠ. ISTRAŽ. ZAGREB GOD. 20 (2011) BR. 4 (114),

STR. 1139-1161

GABELICA, $M$. PRAVAŠKA MLADEŽ... va u drugoj polovici 19. stoljeća, kao kult hrvatskih mučenika poginulih u obrani prava svoje domovine. Ovaj kult je stvoren kao suprotnost kultovima Nikole Šubića Zrinskog i Josipa Jelačića, Hrvata zaslužnih za očuvanje Habsburške Monarhije, koje je njegovala Narodna stranka (Gross, 1973., 124-125, 188-189). Režim u Banskoj Hrvatskoj nije podržavao razvitak ovoga pravaškog kulta, kojim se podgrijavao hrvatski nacionalizam, pa je 1896. godine zabranio skupljanje priloga za prijenos njihovih kostiju u domovinu, što je 1883. godine potaknula Stranka prava. Dolaskom Hrvatsko-srpske koalicije na vlast, 1906. godine, režim je prestao praviti smetnje obilježavanju ovoga kulta (Mijatović, 1999., 148-151).

Uoči Prvoga svjetskog rata obilježavanju kulta Zrinskoga i Frankopana, s jugoslavenskih i protuaustrijskih pozicija, priključili su se Srbi i hrvatski političari jugoslavenske orijentacije, osobito jugoslavenska nacionalistička omladina. Potkraj travnja 1913. godine Zrinsko-frankopanska proslava se prvi put održala u Beogradu, gdje ju je organizirao ideolog hrvatsko-srpskoga narodnog jedinstva, sveučilišni profesor na Beogradskom sveučilištu, Jovan Skerlić. Glavni govornik na toj proslavi bio je jedan od prvaka jugoslavenske nacionalističke omladine, Milan Marjanović. Jugoslavenska nacionalistička omladina kasnije je pisala da je tom proslavom kult Zrinskih i Frankopana izašao iz uskih stranačkih okvira i dobio karakter općenarodne, hrvatsko-srpske ideje slobode. Isticalo se da je beogradska proslava bila potvrda ideje narodnoga jedinstva, koja briše "sve one naše sitne i besmislene provincijalne netolerancije." 54

Srbi i hrvatski političari jugoslavenske orijentacije nastavili su obilježavati Zrinsko-frankopansku proslavu i sljedeće godine. Na prijedlog Franje Hrustića, zastupnika Stranke prava u zagrebačkom zastupstvu, Skupština gradskoga zastupstva, u kojoj su većinu imali zastupnici Hrvatske ujedinjene samostalne stranke, u svibnju 1914. godine donijela je jednoglasnu odluku da će preko Hrvatske zemaljske vlade zamoliti kralja da dopusti prijenos kostiju hrvatskih velikaša iz Bečkog Novog Mjesta u Zagreb. ${ }^{55}$ Potom se Zagrebačko gradsko zastupstvo obratilo zastupstvima ostalih hrvatskih gradova, $\mathrm{s}$ molbom da podupru ovu akciju. Pozivu Zagreba jednoglasno su se odazvala sva gradska zastupstva, pa i ona u kojima su većinu činili Srbi. ${ }^{56}$

Te godine, na dan pogibije Zrinskog i Frankopana, Srpska čitaonica u Šibeniku izvjesila je srpsku zastavu na pola koplja. ${ }^{57}$ Zrinsko-frankopanska proslava u Mostaru organizirana je kao proslava hrvatsko-srpskoga narodnog jedinstva. Đaci svih škola bili su okićeni hrvatskim i srpskim kokardama, pjevale su se hrvatske i srpske pjesme, a pred okupljenim narodom govorili su i srpski političari. ${ }^{58} \mathrm{U}$ uvodnom članku 
DRUŠ. ISTRAŽ. ZAGREB GOD. 20 (2011), BR. 4 (114)

STR. 1139-1161

GABELICA, M.: PRAVAŠKA MLADEŽ..
Srpske Riječi, glasila bosansko-hercegovačkih Srba, navedeno je: "Neka se pomiješa pepeo Zrinjskih i Frankopana s pepelom kumanovskih junaka, neka se sliju u jedinstvenu epopeju borbe za slobodu hrvatsko-srpskog naroda, koji broji 12 milijuna. Uvidimo da nam je spas u bratskoj slozi i tako ćemo doći do slobode, na koju imade pravo naš narod." 59

Frankovci su u vezi s tim pisali da su sve do najnovijih vremena Srbi urotu hrvatskih velikaša interpretirali kao osobnu ambiciju dvojice velikaša, koji su težili kraljevskoj kruni, pa su se kukavički predali kralju, koji ih je potom pogubio. Pisali su da su Srbi tek u najnovije vrijeme, zbog vlastitih političkih interesa, počeli obilježavati uspomenu na njih, no da ih pritom ne predstavljaju kao mučenike, što su po sudu frankovaca hrvatski velikaši bili, nego kao veleizdajnike, odnosno revolucionare, što hrvatski velikaši, po mišljenju frankovaca, nikad nisu bili.60 Pisali su i da jugoslavenski nacionalisti Zrinskom i Frankopanu pripisuju svoju nacionalnu bezbojnost, premda su se ovi velikaši osjećali Hrvatima. Smatrali su da jugoslavenski nacionalisti to čine jer pokušavaju Hrvatima uništiti pomisao na njihovu prošlost, kako bi ih proglasili dijelom jugoslavenskoga naroda, a ne posebnim narodom, a Hrvatsku jugoslavenskom pokrajinom, a ne posebnom državom. ${ }^{61}$

U okolnostima srpske političke ofenzive i jačanja jugoslavenske ideje u hrvatskim pokrajinama, frankovci uoči Prvoga svjetskog rata nisu prijetili pravom hrvatskoga naroda na pobunu protiv vjerolomnoga vladara i na promjenu dinastije, nego su isključivo isticali zajedničke interese habsburške dinastije i hrvatskoga naroda $\mathrm{u}$ obrani od velikosrpske ideologije. Predstavljajući Zrinsko-frankopansku urotu, frankovački ideolozi su 1914. godine o njoj pisali: "S ovom slavom $\mathrm{Hr}$ vati su spajali težnju za oživotvorenjem slobode i nezavisnosti Hrvatske u ovoj monarhiji, za čim su u biti težili i Zrinski i Frankopani. Oni su poginuli u sukobu dviju ideja, ideje očuvanja samostalnosti kraljevstva hrvatskoga i ideje centralizacije monarhije, da od povijesnih državnih tvorbi ne ostane ni traga, nego da se sve pretvori u puke austrijske pokrajine." Isticali su da su urotnici domovinska prava branili u kraljevu interesu te da se ne smije upasti u zamku onih koji u interesu Beograda o Zrinskom i Frankopanu sude kao o revolucionarima, odnosno onih kojima Zrinski i Frankopan služe za pokriće vlastitih revolucionarnih planova. ${ }^{62} \mathrm{~S}$ takvom interpretacijom ovoga kulta zastupnik Stranke prava, Fran Novak, u saborskoj je interpelaciji zatražio da kralj rehabilitira Zrinskog i Frankopana, odnosno da s njih skine veleizdajnički žig, kako bi njihove političke težnje priznao kao opravdane i ostvarive. Novak je smatrao da je u okolnostima sve većega jugoslavenskog nacionalizma hrvatskom narodu potrebno nešto što bi osokolilo hrvatski nacionalizam. ${ }^{63}$ 
DRUŠ. ISTRAŽ. ZAGREB GOD. 20 (2011) BR. 4 (114),

STR. 1139-1161

GABELICA, $M$. PRAVAŠKA MLADEŽ...
Organizirajući spomen na pogibiju Zrinskog i Frankopana, Hrvatsko akademsko podporno društvo sazvalo je u travnju 1914. godine organizacijski odbor, sastavljen od predstavnika svih hrvatskih studentskih klubova, u kojem je vrlo brzo došlo do nesuglasica. Nacionalistička omladina je Zrinsko-frankopansku proslavu shvatila kao demonstraciju hrvatsko-srpskoga narodnog jedinstva, pri čemu se dio proslave trebao organizirati i u Beogradu. Zahtijevali su da na zagrebačkoj proslavi govori prvak jugoslavenske nacionalističke omladine, Milan Marjanović, da proslavi nazoči Srpski sokol te da prostorija u kojoj će se proslava održati bude ukrašena hrvatskim, srpskim i slovenskim trobojnicama. ${ }^{64}$

U prvi su se mah prijedlozima jugoslavenske nacionalističke omladine oduprli svi ostali hrvatski studentski klubovi - Kumičić, Kvaternik, Mlada Hrvatska i Domagoj - koji su najavili održavanje proslave u Starčevićevu domu, bez sudjelovanja nacionalističke omladine. Poziv za održavanje proslave u Starčevićevu domu objavila su oba pravaška lista, Hrvat i Hrvatska. ${ }^{5}$ Riječke su novine kritizirale nacionalističku omladinu zbog zloupotrebe Zrinsko-frankopanske proslave za promidžbu jugoslavenskoga nacionalizma, pa su svojim čitateljima preporučile da sudjeluju u "čisto hrvatskoj proslavi" u Starčevićevu domu. ${ }^{66}$ Međutim, na spomen-proslavi, održanoj 29. travnja 1914. godine u Starčevićevu domu, osim domagojaca i frankovačke mladeži nije bilo predstavnika ni jednoga drugog hrvatskog studentskog društva. ${ }^{67}$

Na nagovor stranačkoga vodstva Starčevićeve Stranke prava, studenti iz akademskih klubova Kvaternik i Mlada Hrvatska napustili su frankovce i domagojce te su pogibiju Zrinskog i Frankopana obilježili u suradnji s nacionalističkom omladinom, u zgradi Hrvatskoga sokola, ${ }^{68}$ pred zagrebačkim gradonačelnikom i hrvatskom kulturnom elitom..$^{69} \mathrm{Tu}$ je proslavu, pod predsjedanjem Slovenca Jenka, otvorio član kluba Mlada $\mathrm{Hr}$ vatska, Mića Anić, a na njoj su govorili Ferdo Šišić, Milan Marjanović te članovi akademskoga kluba Kvaternik, Ante Nikšić i Ilija Despot.70 Dio proslave održan je i u Beogradu, gdje je Ferdo Šišić, na poziv srbijanske studentske omladine, pred prepunom dvoranom i srbijanskom crkvenom, i kulturnom elitom te bivšim ministrima održao predavanje o posljednjim Zrinskima i Frankopanima. Beogradska dvorana bila je ukrašena hrvatskim i srpskim trobojnicama, a nakon Šišićeva predavanja intonirana je hrvatska himna. ${ }^{71}$

Vodstvo Starčevićeve Stranke prava nije se izjašnjavalo o Zrinsko-frankopanskoj proslavi, nego je to prepustilo svojoj mladeži. Milinovačka mladež je kult Zrinskoga i Frankopana tumačila isključivo u protunjemačkom, protumonarhijskom i protudinastičkom smislu. Govoreći na Zrinsko-frankopanskoj akademiji u zgradi Hrvatskoga sokola, u organizaciji naciona- 
DRUŠ. ISTRAŽ. ZAGREB GOD. 20 (2011), BR. 4 (114)

STR. 1139-1161

GABELICA, M.: PRAVAŠKA MLADEŽ... lističke omladine, Ante Nikšić je istaknuo protunjemački karakter njihova kulta. ${ }^{72}$ Objašnjavajući zašto se akademski klub Kvaternik priklonio proslavi nacionalističke omladine, a ne onoj frankovačke mladeži, student David Rubić naveo je da akademski klubovi Kvaternik i Mlada Hrvatska ne tumače slavlje Zrinskoga i Frankopana kako to čini Stranka prava, nego da slave uspomenu na hrvatske mučenike kao simbole prkosa kruni.73 Osvrćući se na frankovačku tvrdnju da se iz Kumičićeva djela Urota Zrinsko-Frankopanska uči ljubiti domovinu, Blaž Jurišić je pisao: "Nije istina, da iz Kumičićeve urote imamo samo naučit ljubiti domovinu i štovati pisca. To znači falsificirati Kumičića. Jer osim toga imamo još nešto naučiti i to je nešto silno, nešto glavno, nešto aktivno, bez čega bi naša ljubav prema domovini bila jalova, što su nekoć i današnji crnožuti (frankovci, op. aut.) priznavali u boljim vremenima, kad su govorili o osveti i mržnji (istaknuo B. Jurišić). No što je glavno, sam im Kumičić dovikuje: lažete! - kad nad mrtvim tijelom posljednjeg Zrinskog kaže: 'A koje su se božice sakupile oko mrtvog trupla? Istina, Slava i Osveta!"'74

\section{ZAKLJUČAK}

Uoči Prvoga svjetskog rata među pravaškom omladinom prepoznatljive su iste podjele koje su bile vidljive i među pravaškim strankama, $\mathrm{s}$ tom razlikom što su te podjele među omladinom bile jasnije i strastvenije definirane. Mladež okupljena u akademskom klubu Kumičić, poput svoje matične stranke, Stranke prava, težila je ostvarenju hrvatskoga nacionalno-političkog programa isključivo u okviru Monarhije, smatrajući da je u tom okviru hrvatstvo najbolje zaštićeno. Za razliku od svoje matične stranke, koja je otvoreno prihvaćala mogućnost ostvarenja ovoga programa unutar dualistički ustrojene Monarhije te oprezno ispitivala teren za priznanje zakonitosti Hrvatsko-ugarske nagodbe, frankovačka mladež je jasno isticala da radi spasa hrvatstva treba odbaciti nepotrebni idealizam i prihvatiti zakonitost Hrvatsko-ugarske nagodbe.

Kao što je Starčevićeva Stranka prava težila suradnji s Hrvatsko-srpskom koalicijom, tako je i njezina mladež, okupljena u akademskom klubu Kvaternik, težila suradnji s jugoslavenskom nacionalističkom omladinom, smatrajući da se srpski dio te omladine može nagovoriti da prihvati pravaški politički, ne i nacionalni, program, ujedinjenje svih hrvatskih zemalja u jednu, jugoslavensku državnu jedinicu unutar Monarhije, koja bi potom stupila u zajedničku državu s Kraljevinom Srbijom. Za razliku od svoje matične stranke, koja je oprezno kritizirala dualistički, njemačko-mađarski karakter Monarhije i neispunjenje dužnosti habsburške dinastije prema hrvatskom narodu, milinovačka mladež je ispovijedala otvorenu mržnju prema Monarhiji i pozivala na osvetu prema dinastiji. 
${ }^{1}$ Izidor Kršnjavi, bivši odjelni predstojnik u vladi Khuen-Hedervaryja, smatrao je kraljevu krunidbenu prisegu iz 1867. godine jedinom valjanom pravnom potvrdom hrvatskoga državnog prava (Hrvatska, 24. ožujak 1914., Dr. Kršnjavi protiv dr. Hinkoviću); Hrvatska ujedinjena samostalna stranka se u članku 5. programa, u "skladu sa državnopravnim ugovorima, zakonima i kraljevskim prisegama", obavezala tražiti ujedinjenje zemalja u kojima "prebiva narod hrvatskog i srpskog imena" (Cipek i Matković, 2006., 638-642). U adresnoj raspravi iz ožujka 1914. godine Svetozar Pribićević se uime Srpske samostalne stranke izjasnio za sjedinjenje Dalmacije i Bosne i Hercegovine s Banskom Hrvatskom na temelju Nagodbe, krunidbene prisege i načela hrvatsko-srpskoga narodnog jedinstva (Stenografski zapisnici Sabora kraljevine Hrvatske, Slavonije i Dalmacije, petogodišta 1913.-1918., Svezak II, Zagreb 1914., 444-446). Tomašićeva Stranka narodnog napretka, u programu iz 1911. godine, isticala je virtualna prava kraljevine Hrvatske na dijelove Bosne i Hercegovine, koji su nekoć bili integralni dio kraljevine Hrvatske (Cipek i Matković, 2006., 630-633).

2 Hrvatski pokret, 25. rujna 1913., Što je hrvatski kurz?

3 Hrvatski državni arhiv (HDA), Pravila društava 1845.-1945., Unutrašnji odjel zemaljske vlade ( UOZV), 13-4 25048/1894.

4 HDA, Pravila društava, UOZV, 13-4 35940/1906., Starčevićansko akademsko podporno društvo.

${ }_{5}^{5}$ HDA, Pravila društava, UOZV, 13-4 35940/1906., Mlada Hrvatska, 13. studenoga 1911., Izbori u Hrvatskom akademskom podpornom društvu.

${ }^{6}$ HDA, Pravila društava, UOZV, 13-4 35940/1906., Pravila Starčevićanske mladosti.

7 HDA, Pravila društava, UOZV, 13-4 35940/1906., Pravila Organizacije starčevićanske srednjoškolske mladosti.

8 Mlada Hrvatska, god. 7., br. 1., Iz nedavne borbe na hrvatskom sveučilištu, 8.-10.

${ }^{9}$ Hrvatska, 21. studenog 1913., Družtvene viesti.

${ }^{10}$ Mlada Hrvatska, godina VII, broj I, Iz nedavne borbe na hrvatskom sveučilištu, 8.-10.

11 Hrvatska, 2. siječnja 1914., Mojim klevetnicima i napadačima.

12 HDA, Pravila društava, UOZV, 13-4 35940/1906., Okružnica svim mladohrvatskim organizacijama.

13 Hrvatsko pravo, 12. listopada 1910., Izjava.

14 Mlada Hrvatska, godina VII, broj I, Osvrt na prošlost Mlade Hrvatske, 4.-7.

15 Mlada Hrvatska, godina VII, broj I, Osvrt na prošlost Mlade Hrvatske, 4.-7.

16 HDA, Pravila društava, UOZV, 13-4 35940/1906., Mlada Hrvatska, 13. studenoga 1911., Izbori u Hrvatskom akademskom podpornom društvu.

17 Mlada Hrvatska, godina VII, broj I, Mladohrvatske organizacije, 19.

18 Hrvatska, 2. siječanj 1914., Mojim klevetnicima i napadačima.

19 Hrvat, 3. prosinac 1913., Pravaštvo na našoj univerzi. 
DRUŠ. ISTRAŽ. ZAGREB GOD. 20 (2011), BR. 4 (114)

STR. 1139-1161

GABELICA, $M$ : PRAVAŠKA MLADEŽ...
${ }^{20}$ Hrvat, 21. studeni 1913., Pokret na universi; Ante Pavelić, 350.-351. ${ }^{21}$ Hrvatski pokret, 25. listopada 1913., Struje među omladinom; Isto, 31. listopada 1913., Borba na sveučilištu.

22 Mlada Hrvatska, godina VII, broj I, Hrvatski akademski klub Kumičić u Zagrebu, 17.-18.

23 Hrvatska, 11. studenog 1913., Vrhovna uprava Stranke prava - kao kuriozum.

24 Hrvatska, 12. studenog 1913., Akademsko pravaško djaštvo i "Vrhovna uprava Stranke prava".

25 Hrvatska, 17. studeni 1913., Izbor za Hrvatsko akademsko podporno društvo.

26 Hrvatski pokret, 17. studenog 1913., Borba na sveučilištu.

27 Hrvat, 21. studeni 1913., Pokret na universi.

28 Hrvat, 17. studeni 1913., Pobjeda pravaša u Hrvatskom akademskom podpornom društvu; Isto, Afera sa viencem na sveučilištu.

29 Hrvat, 14. studeni 1913., Komešanje omladine na hrvatskom sveučilištu.

30 Hrvat, 1. prosinac 1913., Akademska pravaška omladina.

31 Pravaš, godina I, broj I, Naša organizacija, 24.

32 Hrvat, 7. veljače 1914., Omladinski list Pravaš.

33 Pravaš, godina I, broj I, Obračun s frankofurtimašima, 10.-12.

34 Hrvatska, 5. prosinca 1913., Akademska pravaška skupština; Isto, 3. siječnja 1914., Mojim klevetnicima i napadačima, svršetak.

35 Mlada Hrvatska, godina VII, broj I, Odgovor i upozorenje, 19.

${ }^{36}$ Mlada Hrvatska, Izjava pravaške mladosti, 16.-17.

37 Mlada Hrvatska, Mladohrvatska konferencija, 18.-19.

38 HDA, Pravila društava, UOZV, 13-4 35940/1906., Okružnica akademskog kluba Mlada Hrvatska upućena svim mladohrvatskim organizacijama.

${ }^{39}$ Mlada Hrvatska, godina VII, broj I, Mlada Hrvatska, 4.-7.

40 Mlada Hrvatska, godina VII, broj I, Đačke vijesti, 16.

41 Mlada Hrvatska, godina VII, broj II, Hrvatski akademski klub Kumičić u Zagrebu, 40.

42 Mlada Hrvatska, godina VII, broj III i IV, Đačke vijesti, 72.

43 HDA, Pravila društava, UOZV, 13-4 35940/1906., Okružnica akademskog kluba Mlada Hrvatska upućena svim mladohrvatskim organizacijama.

${ }^{44}$ Mlada Hrvatska, godina VII, broj II., Đačke vijesti, 39.-40.

45 Mlada Hrvatska, godina VII, broj I, Politika pravaštva, 1.-3.

46 Pravaš, godina I, broj I, Mjesto programa.

47 Pravaš, godina I., broj 5., Put pravaški prema nacionalističkome, 109.-114.

48 Pravaš, godina I, broj 1., Realna politika, 14.-15.

49 Pravaš, godina I, broj 5., Jednogodišnji rad, 107.-108.

50 Hrvat, 3. prosinac 1913., Djački izkazi proti režimu. 
DRUŠ. ISTRAŽ. ZAGREB GOD. 20 (2011)

BR. 4 (114),

STR. 1139-1161

GABELICA, M. PRAVAŠKA MLADEŽ..
51 Hrvatski pokret, 19. siječnja 1914., Tiszin boravak u Zagrebu.

52 Hrvatski pokret, 21. siječnja 1914., Supilov lov za omladinom.

53 Hrvatski pokret, 21. ožujka 1914., Skupština akademske omladine.

54 Hrvatski pokret, 29. travnja 1914., Proslava Zrinskog i Frankopana.

55 Državni arhiv u Zagrebu (DAZ), Zapisnik o skupštini zastupstva slobodnog i kraljevskog glavnog grada Zagreba održanoj 4. svibnja 1914., 64.

56 DAZ, Predsjedništvo-4., 566.

57 Hrvatska, 2. svibnja 1914., Pokrajinske viesti.

58 Hrvatski pokret, 5. svibnja 1914., Pismo iz Mostara.

${ }^{59}$ Hrvatski pokret, 2. svibnja 1914., Proslava Zrinjskog i Frankopana u Sarajevu.

60 Hrvatska, 28. travanj 1914., Nacionaliste i spomen Zrinskog i Frankopana.

61 Hrvatska, 30. travnja 1914., Spomen-večer Zrinjskih i Frankopana u Starčevićevu domu.

62 Hrvatska, 28. travnja 1914., Nacionaliste i spomen Zrinskog i Frankopana.

63 Hrvatska, 22. travnja 1914., Interpelacija narodnog zastupnika Frana Novaka o dozvoli za prijenos ostataka grofa Petra Zrinskog i Frana kneza Frankopana u domovinu.

64 Hrvatska, 2. svibnja 1914., Krinka je pala.

65 Hrvatska, 27. travnja 1914., Domaće viesti; Hrvat, 27. travanj 1914. Proslava 30. travnja u Zagrebu.

66 Hrvatska, 28. travnja 1914.

67 Hrvatska, 30. travnja 1914., Spomen večer Zrinjskih i Frankopana u Starčevićevom domu.

68 Hrvatska, 11. svibnja 1914., Krinka je pala.

69 Hrvatski pokret, 3. svibanj 1914., Zrinsko-Frankopanski dan u Zagrebu.

70 Hrvat, 2. svibanj 1914., Zrinsko-Frankopanski dan.

71 Hrvatski pokret, 2. svibnja 1914., Proslava Zrinskog i Frankopana.

72 Pravaš, godina I, broj IV, Baština mučenika.

73 Hrvat, 5. svibanj 1914., Krinka je pala.

74 Pravaš, godina I, broj V, Pravaštvo Evgenija Kumičića, 106.-107.

\section{LITERATURA}

Artuković, M. (1991.), Ideologija srpsko-hrvatskih sporova, Zagreb, Naprijed. Gross, M. (1969.), Nacionalne ideje studentske omladine u Hrvatskoj uoči I. svjetskog rata, Zagreb. Historijski zbornik, XXI-XXII: 75-142.

Gross, M. (1970.), Hrvatska politika velikoaustrijskog kruga oko prijestolonasljednika Franje Ferdinanda. Časopis za suvremenu povijest, 2 (2): 9-75.

Gross, M. (1973.), Povijest pravaške ideologije, Zagreb, Sveučilište u Zagrebu - Institut za hrvatsku povijest. 
DRUŠ. ISTRAŽ. ZAGREB GOD. 20 (2011), BR. 4 (114),

STR. 1139-1161

GABELICA, $M$ : PRAVAŠKA MLADEŽ...
Hasanbegović, Z. (2007.), Muslimani u Zagrebu 1878.-1945., Zagreb, Institut društvenih znanosti Ivo Pilar.

Horvat, J. (2006.), Pobuna omladine 1911.-1914., Zagreb, SKD Prosvjeta i Gordogan.

Kršnjavi, I. (1986.), Zapisci - iza kulisa hrvatske politike 2., Zagreb, Mladost. Matijević, Z. (1998.), Slom politike katoličkog jugoslavenstva, Zagreb, Hrvatski institut za povijest.

Matković, S. (2001.), Čista stranka prava 1895.-1903., Zagreb, Hrvatski institut za povijest.

Mijatović, A. (1999.), Zrinsko-Frankopanska urota, Zagreb, Alfa.

Pavelić, A. (1968.), Doživljaji, Madrid, izdavač Višnja Pavelić.

Peršić, I. (2002.), Kroničarski spisi, Zagreb, Državni arhiv u Zagrebu i Hrvatski institut za povijest.

Šidak, J., Gross, M., Karaman, I. i Šepić, D. (1968.), Povijest hrvatskog naroda g. 1860.-1914., Zagreb, Školska knjiga.

\section{OBJAVLJENI IZVORI}

Cipek, T. i Matković, S. (ur.) (2006.), Programatski dokumenti hrvatskih politickih stranaka i skupina 1842.-1914., Zagreb, Disput.

Stenografski zapisnici Sabora kraljevine Hrvatske, Slavonije i Dalmacije, petogodišta 1913.-1918., Svezak II, Zagreb 1914., 444-446.

\section{ARHIVSKI IZVORI}

Hrvatski državni arhiv, Pravila društava 1845.-1945.

Državni arhiv u Zagrebu, Predsjedništvo.

Državni arhiv u Zagrebu, Zapisnik o skupštini zastupstva slobodnog i kraljevskog glavnog grada Zagreba održanoj 4. svibnja 1914.

\section{NOVINE}

Hrvat, Zagreb 1914

Hrvatska, Zagreb 1914.

Hrvatski pokret, Zagreb 1914.

Mlada Hrvatska, Zagreb 1914.

Pravaš, Zagreb 1914.

\section{Party of Rights' Youth at the Croatian University on the Eve of World War I}

Mislav GABELICA

Institute of Social Sciences Ivo Pilar, Zagreb

The subject of this paper is the Party of Rights' ideology on the eve of the First World War, on the basis of the Party of Rights' academic youths' activity at the Croatian university in the stated period. The author starts from an assumption that the political parties in Croatia on the eve of the First World 
DRUŠ. ISTRAŽ. ZAGREB GOD. 20 (2011) BR. 4 (114),

STR. 1139-1161

GABELICA, M. PRAVAŠKA MLADEŽ..

War did not essentially differ with regard to the constitutional position of Croatia within the Monarchy, but according to their relation towards the position of the Serbs inside the Croatian nation. The second hypothesis is that their standpoint concerning the Serbs was mainly conditioned by their opinion regarding the joining of Croatian countries into the community with Serbia. The author therefore observes three types of the mentioned relationship. Some parties, mostly those of Yugoslav national-political orientation, craved for complete equality of Croats and Serbs in Croatia. A part of the Party of Right, which on the eve of the war accepted the possible realization of Croatian statehood even in the Yugoslav context, accepted the existence of Serbs within the Croatian political nation. The other part of the Party of Right, which unconditionally rejected the Yugoslav framework, continued with the non-recognition of the Serbs' existence in Croatia, considering them to be a group of non-Serbian, Vlach origin.

Keywords: Party of Rights' ideology, Party of Rights' youth, Serbs, Austrian-Hungarian Monarchy, First World War

\section{Jugendliche Anhänger der Partei des Rechts an kroatischen Universitäten vor Ausbruch des I. Weltkriegs \\ Mislav GABELICA \\ Ivo Pilar-Institut für Gesellschaftswissenschaften, Zagreb}

Der vorliegende Artikel analysiert die Tätigkeit der vor dem I. Weltkrieg an kroatischen Universitäten studierenden Parteijugend der Partei des Rechts und präsentiert die zeitgenössische Partei-Ideologie. Der Verfasser des Artikels geht von der Annahme aus, dass sich die kroatischen politischen Parteien der Vorkriegszeit in ihren Ansichten über die staatsrechtliche Position Kroatiens innerhalb der österreichisch-ungarischen Monarchie im Wesentlichen nicht voneinander unterschieden; Abweichungen gab es allerdings in Bezug auf die Position der Serben innerhalb des kroatischen Volkes. Der Autor setzt ferner voraus, das Verhältnis zwischen Serben und Kroaten sei hauptsächlich dadurch bedingt gewesen, welche Einstellung man zur Einbindung der kroatischen Stammländer in eine Staatengemeinschaft mit Serbien hatte. Nach Ansicht des Autors sind dreierlei Einstellungen nachvollziehbar: Einige Parteien, hauptsächlich jugoslawischer national-politischer Orientierung, gingen von der vollkommenen nationalen Gleichstellung von Kroaten und Serben im Königreich Kroatien und Slawonien aus; ein Teil der Anhänger der Partei des Rechts, die vor Kriegsausbruch ihre Akzeptanz kroatischer politischer Eigenständigkeit auch innerhalb eines 
DRUŠ. ISTRAŽ. ZAGREB GOD. 20 (2011), BR. 4 (114),

STR. 1139-1161

GABELICA, M. PRAVAŠKA MLADEŽ... gemeinsamen jugoslawischen Staates bekundet hatten, gestand den in Kroatien lebenden Serben volles Existenzrecht zu; der übrige Teil der Anhängerschaft der Partei des Rechts verwarf jegliche Mitgliedschaft Kroatiens in einem jugoslawischen Staat und negierte weiterhin die Existenz von Serben in den kroatischen Stammländern, indem sie diese als nicht-serbische Volksgruppe walachischer Abstammung betrachtete.

Schlüsselbegriffe: Ideologie der Partei des Rechts, Parteijugend der Partei des Rechts, Serben, ÖsterreichUngarn, Erster Weltkrieg 